Brit. J. industr. Med., 1960, 17, 181.

\title{
A COMPARISON OF THE "HIGH-ALTITUDE" AND "HIGH-PRESSURE" SYNDROMES OF DECOMPRESSION SICKNESS
}

\author{
BY \\ M. DE G. GRIBBLE* \\ From the Royal Air Force Institute of Aviation Medicine, Farnborough, Hants
}

(RECEIVED FOR PUBLICATION NOVEMBER 17, 1959)

Decompression sickness is an illness which occurs in divers and caisson workers on return to normal atmospheric pressure after working at very high pressures, and in airmen on reaching very low pressures at great altitude. The disease seen after exposure to high pressure is described and compared with that seen on exposure to great altitude. Mild cases show little difference, but serious ones vary sufficiently to justify division of the disease into two distinct syndromes, high-pressure and high-altitude decompression sickness.

Both syndromes are caused by the formation of gas bubbles in the blood and body fluids when the tension of dissolved gases becomes sufficiently greater than that of the surrounding atmosphere. These bubbles are composed of a mixture of gases, but their formation is determined mainly by the degree of supersaturation with nitrogen. The diver must first absorb excess nitrogen on exposure to pressure, and it is the subsequent release of this excess on return to the surface which causes decompression sickness; since his stay at pressure is limited, bubbles arise mainly from tissues which can absorb the excess gas readily. In the airman, on the other hand, all tissues are completely saturated with nitrogen before he is exposed to low pressure, and bubbles may arise equally well from any tissue. Nitrogen is much more soluble in fat than in water, so that fatty tissues can form a large reservoir of dissolved nitrogen which may later form a source of bubbles; but the blood supply of fat is poor and nitrogen diffuses slowly through it, hence although the potential capacity of the fatty tissues for excess nitrogen is great, they can only absorb it slowly. Obesity is therefore a major hazard in high-altitude decompression sickness, but relatively unimportant in the high-pressure syndrome. Liability to the airman's sickness increases markedly with age, but the incidence of the diver's syndrome is affected both much less and later in life.

Decompression also involves great changes in the working atmosphere, and the effects of these and their possible influence on decompression sickness are discussed.

High-pressure Decompression Sickness (Divers' Bends and Caisson Disease)

According to Hill (1912), the condition was first described in caisson workers by Pol and Watelle (1854) and in divers by de Mericourt (1868); both authors realized that the cause was the reduction in pressure and not merely exposure to pressure. It occurs only if the pressure has been high and the decompression rate fast (Bert, 1878; Hill, 1912), and in fact, it is never seen after dives to less than $42.5 \mathrm{ft}$. (2.25 atmospheres) and it can be prevented by gradual decompression (Haldane, 1907). The

*Present address: Department of Pathology, Maryfield Hospital, Dundee. most common symptom is joint pain, "bends", which occurs either during decompression or up to 14 hours afterwards (Snell, 1896); this passes off in time, varying from a few hours to nearly a week, or immediately on recompression, and is not dangerous, though it can be extremely severe. The faster the rate of decompression, the greater the frequency of "bends" and of all other symptoms. Itching, particularly of the skin of the legs, is almost as common as "bends" and equally harmless. Respiratory symptoms occur rarely, and are poorly described; the symptom known as "chokes" appears to be characterized by dyspnoea without cyanosis and a sense of oppression in the chest (Oliver, 1899), and Coleman (1904) describes them as "urgent 
attacks of dyspnoea, during which the patient felt his lungs distended, then a cough was set up, during which quantities of gas . . . issued from the mouth". Epileptiform attacks and temporary vertigo occur frequently in caisson work (Snell, 1896; Heller, Mager, and von Schrötter, 1900) but there is no permanent damage. The most serious consequence of decompression is a spastic paraplegia with paralysis of the bladder and urinary retention, and though often permanent, partial and even complete recovery is surprisingly frequent (Blick, 1909), but in the past, many succumbed eventually to renal infection or bed sores.

Aseptic necrosis of bone may occur, but symptoms do not appear until three or four months after exposure; it is fairly massive, often multiple, and usually affects the head or lower diaphysis of the femur and upper tibia, and occasionally the upper humerus (Kahlstrom, Burton, and Phemister, 1939).

Many deaths are recorded, and these fall into two groups, those dying within a few hours of decompression and those dying from the late secondary effects of paraplegia (Heller et al., 1900). Many of those dying immediately showed premonitory mottling of the skin, subcutaneous emphysema, or complained of abdominal pain.

\section{High-altitude Decompression Sickness}

The first to record symptoms of decompression sickness at low pressures was von Schrötter (1906), according to Boycott and Haldane (1908). He exposed himself to an atmosphere of $230 \mathrm{~mm}$. $\mathrm{Hg}$ $(29,500 \mathrm{ft}$.) and noticed joint pains, but concluded that they could not have been due to caisson disease; Boycott and Haldane comment, however, "we think . . . he was probably mistaken, and that the risk of caisson disease at very low pressures ought to be taken into account". The first authentic case of high-altitude decompression sickness was not recognized, however, until 1938 (Boothby and Lovelace), though it rapidly became recognized as an entity with the great increase in high-altitude flying during the second world war.

The following account, based on published descriptions and personal observation, is practically confined to subjects exposed to low pressures in a partially exhausted "decompression chamber", rather than in aircraft. Under these conditions, high-altitude decompression sickness is never seen below $23,000 \mathrm{ft}$. ( $307 \mathrm{~mm}$. $\mathrm{Hg}$ ), and extremely rarely below $30,000 \mathrm{ft}$. ( $225 \mathrm{~mm}$.), but it occurs increasingly frequently at greater altitudes (Gray and Masland, 1946).

The most common symptom is joint pain, apparently identical with divers' bends, also occurring most frequently in the knees, though any joint may be affected except those of the spine, ribs, sternum, and skull (Swann and Rosenthal, 1944; Gray, Mahady, Masland, and Wigodsky, 1946). Pain is felt in or around the joint, and is often localized to muscle insertions (Gray and Masland, 1946); itching of the skin is also frequent, and as in the high-pressure form, is most common in the legs; on descent both symptoms disappear completely at about $27,000 \mathrm{ft}$. Faintness occurs, but as the incidence falls off rapidly in successive exposures it is possibly partly psychological in origin (Ferris and Engel, 1951) though in some patients it precedes collapse after descent. Chest pain, known as "chokes", occurs more frequently and differs somewhat from high-pressure chokes; it consists of a substernal burning pain with a deep-seated nonproductive cough, both of which are aggravated by deep respiration, and dyspnoea with a feeling of suffocation and apprehension (Gray et al., 1946). Patchy erythema and cyanosis, and localized emphysema of the skin also occur occasionally, as in the high-pressure form, and frequently presage collapse.

The neurological symptoms are quite different from those of high-pressure decompression sickness; paralysis is extremely rare, and when it does occur, it is found at least as commonly in the arm as in the leg. The first recognized case of high-altitude decompression sickness (Boothby and Lovelace, 1938) presented as a temporary paraplegia, but in the millions of real and simulated high-altitude flights made since, only four further instances have been described; two of these were evanescent (Masland, 1943; Benzinger, 1950), and only two showed a persistent paraplegia in any way resembling the lesion typical of high-pressure decompression casualties (Royal Air Force, 1950; von Döbeln and Höök, 1954). The only common symptom is homonymous scintillating scotomata, and these, like chokes, may persist for up to an hour after recompression but are never permanent.

The most serious manifestation is post-decompression shock, which, although very rare, may be fatal. Clinical evidence of shock nearly always appears after recompression is complete, and may be delayed for as long as eight hours. Subjects leave the chamber, usually having had some other symptom, but more or less fit; later they feel faint and ill, are often nauseated, frequently vomit, and are found to have a cold, clammy, cyanosed skin, shallow rapid respiration, feeble pulse, and low systolic and pulse pressures; the haematocrit is raised, and there is oliguria (Goggio and Houck, 1945; Masland, 1948; Adler, 1950; Haymaker and Davison, 1950; Sproull, 1951; Cotes, 1953; 
Halbouty and Long, 1953; Haymaker, Johnston, and Downey, 1956).

In one million man-exposures to $30,000 \mathrm{ft}$. and above there were about 150 serious cases of postdecompression shock $(0.015 \%)$, of which seven were fatal (Adler, 1950). With a slightly more severe mean exposure, Roxburgh (1951) found nine severe cases of collapse, including two deaths, in 20,000 decompressions $(0.045 \%)$, and of these nine patients, only one was less than 27 years old. In a further series of 61 decompressions with an average age about 10 years more than in the first two, the serious collapse rate rose to $6.5 \%$ (four cases), of which one was fatal (Roxburgh, 1951).

\section{Pathology of Fatal Cases of Decompression Sickness}

The main necropsy findings in high-altitude postdecompression shock have been pleural and pericardial effusions, oedema of the lungs, acute dilatation of the heart, congestion and oedema of the brain, and a fatty liver (Goggio and Houck, 1945; Adler, 1950; Haymaker and Davison, 1950; Roxburgh, 1951; Haymaker et al., 1956). In the brain, the white matter is mainly affected, showing petechiae, and perivascular oedema progressing to demyelination; in the gray matter, ischaemic changes may occur at the bases of the sulci. In the cord, the main finding is perivascular oedema and swelling of nerve fibres in the gray matter (Haymaker and Johnston, 1955). In all the cases in which it has been sought fat embolism has been found, but the emboli are never numerous, and were thought to be probably of no clinical significance (Haymaker and Davison, 1950; Haymaker and Johnston, 1955).

A syndrome corresponding to post-decompression shock probably occurs in high-pressure decompression sickness (Haymaker, 1957) and a case was described by Rudge (1907). Deaths occurring immediately after decompression from high pressures are in general poorly described and necropsy reports are inadequate, but death appears to have occurred in one of two ways: in the first it was sudden, gas bubbles were found freely in the heart and great vessels, and the cause was probably massive air embolism (Boycott, Damant, and Haldane, 1908); Hill, 1912; Haymaker and Johnston, 1955; Sillery, 1958); in the other, death occurred in coma between 15 hours and four days after decompression, and the main necropsy finding was visceral congestion, bubbles being rarely seen (Keays, 1909). This last condition may be analogous to high-altitude post-decompression shock, but the occurrence of shock after exposure to pressure has been very much less emphasized than it has after exposure to altitude.

There are few descriptions of necropsy changes in the brain in high-pressure decompression sickness, and these usually mention petechiae or larger haemorrhages (Blick, 1909), but in one case, white matter changes were found similar to those in highaltitude decompression sickness (Haymaker and Johnston, 1955). The cord changes, unlike those in high-altitude deaths, are more prominent than those in the brain, affect the white, rather than the gray matter, and comprise petechiae, frank haemorrhage, and oedema (Blick, 1909; Haymaker and Johnston, 1955). Fat embolism in fatal cases of highpressure decompression sickness has been recorded only twice; the first case, one of caisson disease (Muir, 1941) had large and widespread emboli (Lendrum, 1958), which may well have contributed to death, and similar findings have more recently been recorded in a diver (Haymaker and Johnston, 1955).

Mild cases of the two syndromes are very similar, but severe cases differ significantly. Persistent paraplegia, aseptic bone necrosis, and death due to gross air embolism are characteristics of highpressure decompression sickness, whereas postdecompression shock is very much commoner after exposure to altitude. Degenerative changes in the central nervous system occur in both syndromes, but are found mainly in the gray matter of the cord after exposure to pressure, and in the white matter of the brain in high-altitude decompression sickness.

\section{An Aetiological Comparison of the Two Forms of Decompression Sickness}

The cause of both syndromes is intimately associated with the formation of gas bubbles in the blood and tissues on decompression. The factors governing the formation of these bubbles are, however, different in the two conditions, for the diver is first compressed, and then returns to a normal state of decompression, whereas the airman is first decompressed, returning, on descent, to a normal state of compression.

\section{Tissue Nitrogen Saturation, Obesity, and Age}

Though nitrogen forms only part of the content of these bubbles, it is the most important factor in both their initiation and maintenance (Haymaker, 1957). As the diver descends, excess nitrogen dissolves in the tissues, but he must be exposed to nitrogen under pressure for a definite time in order to absorb sufficient gas to form bubbles on decompression. The rate at which tissues take up excess 
gas depends mainly on their blood supply, and the total mass they can absorb, on its solubility in the tissue substance. Nitrogen is five times more soluble in fat than in water (Vernon, 1907), and the tissues may be divided into the fatty and the watery, according to their affinity for nitrogen. Watery tissues have a low storage capacity for nitrogen, and usually a good blood supply, and are therefore easily saturated. Fatty tissues, on the other hand, have a large nitrogen storage capacity, but a poor blood supply, and are saturated only with difficulty, particularly since the diffusion rate of nitrogen through fat is slow (Campbell and Hill, 1933a). Fatty tissues are thus approximately synonymous with "slowly saturating tissues" and watery tissues with "rapidly saturating" ones.

In man, the time taken to reach a mean body saturation of even $94 \%$ was estimated to be about five hours (Boycott et al., 1908) but "in parts of the body that are the seat of bends, a still slower rate of saturation may exist", and Campbell and Hill (1933a and b) produced evidence that the rates of saturation found experimentally were, in fact, considerably slower than this. Caisson workers usually work four-hour shifts, and divers spend up to half an hour on the bottom, but in deep dives perhaps only 10 minutes. Thus caisson workers are rarely fully saturated at the end of a shift, and divers do not approach full saturation when they start decompression. Hence in high-pressure decompression sickness there is less danger of bubbles arising from the slowly saturating tissues, whereas since the airman is completely saturated before decompression they may form in any tissue.

The exact way in which bubbles form in the body is still not certain. There is little doubt that bubble formation in both types of decompression sickness depends on the tissue fluids becoming supersaturated with nitrogen, and that the degree is determined by the relative pressure drop, not by the total mass of gas held in solution; in fact in both syndromes bubbles can be demonstrated only after the pressure has fallen by a factor of about $2 \cdot 25$ (Haymaker, 1957).

The diver differs from the airman in two respects: first, the relative pressure drops experienced are very much greater, and secondly his slowly saturating tissues are by no means fully saturated when decompression starts. Bubble formation appears to be due to excessive supersaturation, the main sources of which are the more rapidly saturating watery tissues.

The same factors govern both saturation and desaturation so that watery tissues in the highaltitude syndrome desaturate quickly, part of their nitrogen load being shed even during ascent, but the nitrogen tension of the fatty tissues remains much higher than that of the blood throughout their long desaturation time. Hence the danger in the airman arises largely from the slowly saturating tissues, though the relative pressure drop is comparatively small.

This conclusion differs from that of Boycott et al. (1908), Hill (1912), and Haldane and Priestly (1935), who all considered the slowly saturating tissues to be the main cause of trouble in high-pressure decompression sickness. This would be the case only if exposure to high pressure were long enough to allow full saturation, but this is not so in practice. Obesity should then be more important in determining susceptibility to high-altitude than to highpressure decompression sickness; although Boycott and Damant (1908) showed that fatness considerably increased the susceptibility of rats and guinea-pigs to high-pressure decompression death, this was only after complete saturation. Smith (1899) had the impression that in caisson work "heavy" individuals were more susceptible than "spare" ones, but Paton and Walder (1954) were unable to find any correlation between weight and susceptibility, and suggest that "too much importance may be attached to excessive weight in this connexion". In high-altitude decompression sickness, on the other hand, Motley, Chinn, and Odell (1945), Gray (1951), and Cotes and Gronow (1952) showed unequivocally that susceptibility increased markedly with obesity, independently of age.

Both respiratory exchange and circulation are said to decline in middle age (Boycott and Damant, 1908; Cournand, Riley, Breed, Baldwin, and Richards, 1945; Bateman, 1951), and since both would retard the processes of nitrogen exchange, one would expect an increase in susceptibility to high-altitude decompression sickness with increasing age. In fact, there is a dramatic increase in the incidence of high-altitude post-decompression collapse in the 30-40 age group compared with the 20-30 age group (Gray, 1951; Roxburgh, 1951; Cotes and Gronow, 1952). On the other hand, in high-pressure decompression sickness, the rate of nitrogen saturation would be reduced to the same degree as that of desaturation, and such an increase would not be expected. Though there is a general impression that liability to high-pressure decompression sickness does increase with age, the evidence provided both by Snell (1896) and Hill (1912) is inconclusive, and Paton and Walder (1954) found that in caissoniers working six- to eight-hour shifts the incidence of bends did not rise until after the age of 40 and rose steeply only after 50. 
The Inevitable Concomitants

Exposure to either high or low pressure necessarily introduces other factors, and these inevitable concomitants are quite different in the two forms of decompression sickness.

In high-pressure decompression sickness, an increase of pressure involves an increase in the partial pressure of all the gases in the atmosphere, which may cause severally, carbon dioxide poisoning, nitrogen narcosis, and oxygen poisoning. Carbon dioxide poisoning was a common complication of diving until Haldane (1907) pointed out the cause and remedy. Nitrogen narcosis (Bean, 1945) has never been clearly distinguished from carbon dioxide poisoning; disorientation, elation, irresponsibility, and loss of consciousness with convulsions occur, and Bean suggested that excessive dilution of a gas mixture with large numbers of heavy, relatively immobile nitrogen molecules causes physical reduction of carbon dioxide diffusion, so that the tissues fail to clear it adequately and become poisoned. This idea is confirmed by the fact that argon, the effects of which can only be physical, has a similar and greater effect than nitrogen, corresponding with its greater density. Oxygen poisoning, which was first recognized by Paul Bert (1878), causes convulsions, congestion, and oedema of the lungs, with inflammatory changes in the alveoli. At three atmospheres of oxygen, sufficient is carried in physical solution in the plasma to satisfy all the metabolic needs of the body (Bean, 1945), and above this pressure its tension in the tissues is sufficient to inhibit the function of enzymes with -SH side chains and metallic prosthetic groups. Lastly divers, though not caissoniers, are bound to work in a cold atmosphere, except in tropical waters, and cold is said to cause an increase in both types of decompression sickness (Cook, 1951).

The greatest hazard at altitude is lack of oxygen. When breathing air signs of cerebral anoxia appear at $10,000-12,000 \mathrm{ft}$. $(523-485 \mathrm{~mm}$. Hg), with loss of consciousness at about $20,000 \mathrm{ft}$. $(350 \mathrm{~mm}$.); breathing oxygen at $30,000 \mathrm{ft}$. (225 mm.) is equivalent to breathing air at ground level, and at 38,000$40,000 \mathrm{ft}$. (155-141 mm.) it is equivalent to air at $10,000-12,000 \mathrm{ft}$; the alveolar oxygen tension is therefore less than normal, even when breathing pure oxygen, at all altitudes greater than $33,000 \mathrm{ft}$. Little is known of the effect of the anoxia itself on the decompression sickness syndrome, but though Jones (1951) suggested that the increased respiratory exchange and cardiac output, due to mild anoxia, should increase nitrogen elimination and lower the incidence of the syndrome, most workers are subjectively convinced that oxygen lack in- creases either its incidence, its severity, or both.

High-altitude decompression is also complicated by expansion of gas in closed cavities, particularly the gut, causing discomfort or even severe colic, and also in the middle ear and nasal sinuses if the ostia are obstructed.

No account is taken of these inevitable concomitants in practically any of the work done on decompression sickness in either man or animals, but they may not be quite so unimportant as is usually assumed, and their neglect cannot easily be justified.

\section{Conclusion}

Decompression sickness is essentially a single entity, but the diver's syndrome and the airman's differ significantly. Clinically, sequelae are seen after high-pressure decompression sickness, shock after the high-altitude syndrome; pathologically, air embolism is seen only after exposure to pressure, and lesions of the central nervous system, though found in both syndromes, occur in different places in each. Aetiologically, the mass of bubbles originates in the watery tissues in the high-pressure syndrome, but in the fatty tissues on exposure to altitude. Lastly, simple pressure changes are inevitably accompanied by other environmental changes, quite different in the two conditions, and likely to have distinct physiological effects, but though they almost certainly influence the development of each syndrome, extremely little is known of their actions, and their importance has previously been overlooked.

I would like to thank Air Commodore W. K. Stewart, C.B.E., A.F.C., and Professor F. G. Young, F.R.S., for much help and encouragement.

\section{REFERENCES}

Adler, H. F. (1950). U.S.A.F., S.A.M., Project Report, Randolf A.F.B., Texas.

Bateman, J. B. (1951). In Fulton, J. F., Decompression Sickness. [National Research Council, Washington, D.C.] Saunders, Philadelphia.

Bean, J. W. (1945). Physiol. Rev., 25, 1.

Bean, J. W. (1945), Physiol. Rev., 25, 1.

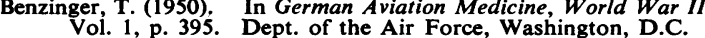
Vol. 1, p. 395. Dept. of the Air Force, Washington, D.C.
Bert, P. (1878). La Pression Barométrique. [Barometric Pressure]. Masson, Paris. (translated by Hitchcock, M. A., and Hitchcock F. A., 1943. College Book Co., Columbus, Öhio).

Blick, G. (1909). Brit. med. J., 2 , 1796

Boothby, W. M., and Lovelace, W. R. (1938). J. aviat. Med., 9, 172 Boycott, A. E., and Damant, G. C. C. (1908). J. Hyg. (Camb.), 8, 445. ,- 1 , and Haldane, J. S. (1908). Ibid., 8, 342

$\longrightarrow$, and Haldane, J. S. (1908). J. Physiol.' (Lond.), 37, 355.

Campbell, J. A., and Hill, L. (1933a). Quart. J. exp. Physiol., 23, 197.

$\longrightarrow,-$, (1933b). Ibid., 23, 219

Coleman, J. B. (1904). Brit. med. J., 2, 1574

Cook, S. F. (1951). In Fulton, J. F., Decompression Sickness.

Cotes, J. E. (1953). Air Ministry, F.P.R.C. rep. no. 825

Cond Gronow, D. C. G. (1952). Ibid., 795.

Cournand, A., Riley, R. L., Breed, E. S., Baldwin, E. deF., and Richards, D. W. (1945). J. clin. Invest., 24, 106.

Döbeln, W. von, and Höök, O. (1954). Quoted by Haymaker, W. and Johnston, A. D. (1955). Milit. Med., 117, 285. 
Ferris, E. B., and Engel, G. L. (1951). In Fulton, J. F., Decompression Sickness. Philadelphia.

Goggio, A. F., and Houck, G. H. (1945). War Med. (Chicago), 7, 152. Gray, J. S. (1951). In Fulton, J. F., Decompression Sickness. Philadelphia.

- and Masland, R. L. (1946). J. aviat. Med., 17, 483.

Mahady, S. C. F., Masland, R. L., and Wigodsky, H. S. (1946). Ibid., 17, 333 .

Halbouty, M. R., and Long, D. R. (1953). Jbid., 24, 301.

Haldane, J. S. (1907). Quoted by Haldane, J. S., and Priestley, J. G. (1935), Respiration. Clarendon Press, Oxford.

, and Priestley, J. G. (1935). Respiration. Clarendon Press, Oxford.

Haymaker, W. (1957). In Lubarsch, O., Henke, F., and Rössle, R., Handbuch der speziellen pathologischen Anatomie und Histologie, Vol. 13, Pt 1. Springer, Berlin.

-, and Davison, C. (1950). J. Neuropath. exp. Neurol., 9, 29.

and Johnston, A. D. (1955). Milit. Med., 117, 285.

- and Downey, V. M. (1956). J. aviat. Med., 27, 2.

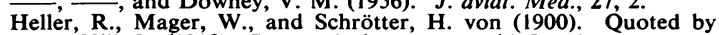
Hili, L. (1912), Caisson Sickness. Arnold, London.

Hill, L. (1912). Caisson Sickness. Arnold, London.

Jones, H. B. (1951). In Fulton, J. F., Decompression Sickness. Philadelphia.

Kahlstrom, S. C., Burton, C. C., and Phemister, D، B. (1939). Surg. Gynet. Obstet., 68, 129.

Keays, F. L. (1909). Quoted by Hill, L. (1912), Caisson Sickness. Arnold, London.
Lendrum, A. C. (1958). Personal communication.

Masland, R. L. (1943). Quoted by Haymaker, W., and Johnston A. D. (1955). Milit. Med., 117, 285.

- (1948). Arch. Neurol. Psychiat. (Chicago), 59, 445.

Mericourt, Le Roy de (1868). Quoted by Hill, L. (1912). Caisson Sickness. Arnold, London.

Motley, H. L., Chinn, H. I., and Odell, F. A. (1945). J. aviat. Med. 16, 210 .

Muir, R. (1941). Text-book of Pathology, 5th ed. London.

Muir, R. (1941). Text-book of Pathology, 5th ed. London.

Pator, W. D. M., and Walder, D. M. (1954). Spec. Rep. Ser. med. Res. Coun. (Lond.), No. 281.

Pol, B., and Watelle, T. J. J. (1854). Quoted by Hill, L. (1912), Caisson Sickness. Arnold, London

Royal Air Force (1950). Institute of Aviation Medicine, Medical Records.

Roxburgh, H. L. (1951). Air Ministry, Communication to D.G.M.S Rudge, F. H. (1907). Lancet, 2, 1675.

Schrötter, H. von (1906). Quoted by Boycott, A. E., and Haldane, J. S. (1908), J. Physiol. (Lond.), 37, 355.

Sillery, R. J. (1958). A M.A. Arch. Path 66, 241.

Smith, A. H. (1899). In Albutt, T. C., A System of Medicine, Vol VII. Macmillan, London.

Snell, E. H. (1896). Compressed Air Illness. Lewis, London.

Sproull, D. H. (1951). Air Ministry, F.P.R.C., Memo No. 25.

Swann, H. H., and Rosenthal, T. B. (1944), National Research Council, U.S.A., S.A.M. report.

Vernon, H. M. (1907). Proc. roy. Soc. B., 79, 366. 